\title{
Kineto-stratigraphy at Hvideklint, Møn, Denmark and its regional significance
}

JAMES S. ABER

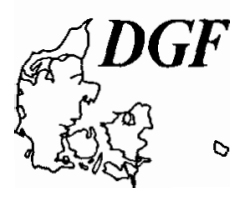

Aber, J. S.: Kineto-stratigraphy at Hvideklint, Møn, Denmark and its regional significance. Bull. geol. Soc. Denmark, vol. 28. pp. 81-93. Copenhagen, February 22nd, 1980. https://doi.org/1037570/bgsd-1979-28-11

\begin{abstract}
A detailed investigation of the deformed drift and chalk floes at Hvideklint, Mon was carried out using the kineto-stratigraphic principle. Various structural evidence show that glacier advances coming from the northeast caused the thrusting and folding displayed at Hvideklint. The chalk floes were probably derived from the Fakse Bugt area, and pushed into their present positions in front of the advancing ice. When the ice overrode the floes, chalk-till mélange, an example of glaciodynamic mélange, was created by subglacial deformation. Although a minor amount of water due to pressure-melting may have formed during thrust-ing, these deformations probably affected materials that were largely frozen. Three till units with as-sociated stratified drift are present at Hvideklint. A covering discordant till and an upper dislocated till are ascribed to the main Weichselian glaciation - the Northeast Advance. These two tills overlie a lower dislocated till that is assigned to the Weichselian Old Baltic Advance. On the basis of pebble counts, the discordant and upper dislocated tills at Hvideklint correspond to the thick, upper dislocated till at Mons Klint, while the lower dislocated till at Hvideklint matches the thin, lower dislocated till at Møns Klint. The Young Baltic Advance supposedly caused the latest dislocations at Møns Klint, but this advance apparantly did not disturb the Hvideklint section.
\end{abstract}

James S. Aber, Dept. of Earth Science, Chadron State College, Chadron, Nebraska 69337 U.S.A. August 7 th, 1979.

\section{Introduction}

In recent years, the glacial stratigraphy of Denmark has been reinvestigated using the kineto-stratigraphic principle of Berthelsen (1978). A kineto-stratigraphic drift unit was originally defined as, »... the sedimentary unit deposited by an ice sheet or stream possessing a characteristic pattern and direction of movement «. (Berthelsen 1973, p. 23). A primary method in kineto-stratigraphy is the study of glaciodynamic structures such as folds and thrust faults in disturbed sequences. From this, the direction of ice movement which caused the deformations can be deduced and used as a stratigraphic indicator. Additional kinds of evidence such as striations, till-stone orientation, paleocurrent directions, and so on are also used to establich the directions of glacier advances, as well as provenance indicators such as reworked fossils and stone counts.

A number of kineto-stratigraphic studies have now been conducted (see Berthelsen, 1978 for a summary), and a coherent picture of Weichselian stratigraphy is beginning to emerge. In southern Denmark, three Weichselian kineto-stratigraphic units are generally recognized and related to the following glacier advances: oldest the Old Baltic Advance, then the Northeast Advance, and finally the Young Baltic Advance (Berthelsen 1973, 1978; Petersen \& Konradi 1974; Jacobsen 1976; Berthelsen, Konradi \& Petersen 1977; Sjørring 1977; Ehlers 1978). The Old and Young Baltic Advances both came out of the Baltic Basin and moved from southeast to northwest over the area. Drift from these advances is characterized by a relatively high proportion of Paleozoic sedimentary rocks derived from the Baltic region. The Northeast Advance was the main Weichselian glaciation that came from the northeast and reached westward to the Main Stationary Line in central Jylland. Drift from this advance is marked by a relatively large amount of crystalline stones from the Fennoscandian Shield and fewer Paleozoic stones. Since Old Baltic drift overlies marine Eemian strata (Petersen \& Konradi 1974), all three kineto-stratigraphic units are of Weichselain age. In southwestern Denmark on Als, Sjørring (1977) has correlated the Old Baltic, Northeast, and Young Baltic Advances with respectively the Brandenburg, Frankfurt, and Pommern stages of northern Germany. 


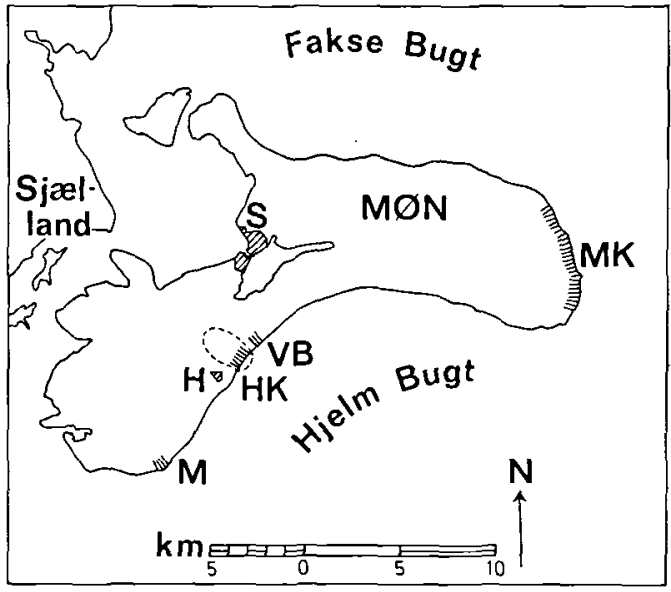

Fig. 1. Map of localities on Møn: $H K=$ Hvideklint, $M K=$ Mons Klint, $\mathrm{M}=$ Madsesklint, $\mathrm{VB}=$ Vagtbo Bakke, $\mathrm{H}=$ village of Hjelm, and $S=$ city of Stege. Dashed line shows position of kuppelbakke in which Hvideklint is cut.

The island of Møn (fig. 1) in southeastern Denmark projects into the western end of the Baltic Sea. Undisturbed bedrock underlies Møn at elevations of -20 to $-40 \mathrm{~m}$ (Haarsted 1956, Berthelsen 1979) and presumably consists of Upper Cretaceous white chalk. At the surface, exposures display deformed Quaternary strata and detached chalk floes. In general, Møn has been subjected to Weichselian glacier advances from two different directions - from northeast to southwest and from southeast to northwest - and the glaciotectonic structures and landforms re- flect this (Haarsted 1956). Berthelsen (1979) believes that the glaciotectonic disturbances on Møn occurred in largely frozen materials, although minor quantities of meltwater may have formed along thrust surfaces. In addition, he concluded that all of the contorted drift and chalk floes are allochthonous in a glaciotectonic sense.

Along the concave south coast of Møn, several exposures of deformed strata are found, including Hvideklint. At Hvideklint, several upthrust floes of Upper Campanian and Lower Maastrichtian white chalk (Surlyk, 1971), covered and separated by deformed drift, form a cliff nearly one $\mathrm{km}$ long and up to $20 \mathrm{~m}$ high (fig. 2). The cliff cuts through the end of an elongated, irregular hilly area, which resembles the landform on Fyn that Smed (1962) called kuppelbakke. Chalk has been observed underlying high hills at several places in the Hvideklint kuppelbakke, so it seems likely that much of the hilly area is underlain by upthrust chalk floes. Likewise, low ridges extend out from Hvideklint on the seafloor and may also represent chalk floes. Some geologists have concluded that the glacial features on western Møn were formed mainly by an ice lobe advancing out of Hjelm Bugt from the south (Gripp, 1948; and Surlyk, 1971). Haarsted (1956) and Berthelsen at al. (1977), however, believed that glacier advances from the northeast were largely responsible for creating the hilly areas of western Møn, and that these features were later modified by the Young Baltic Advance.
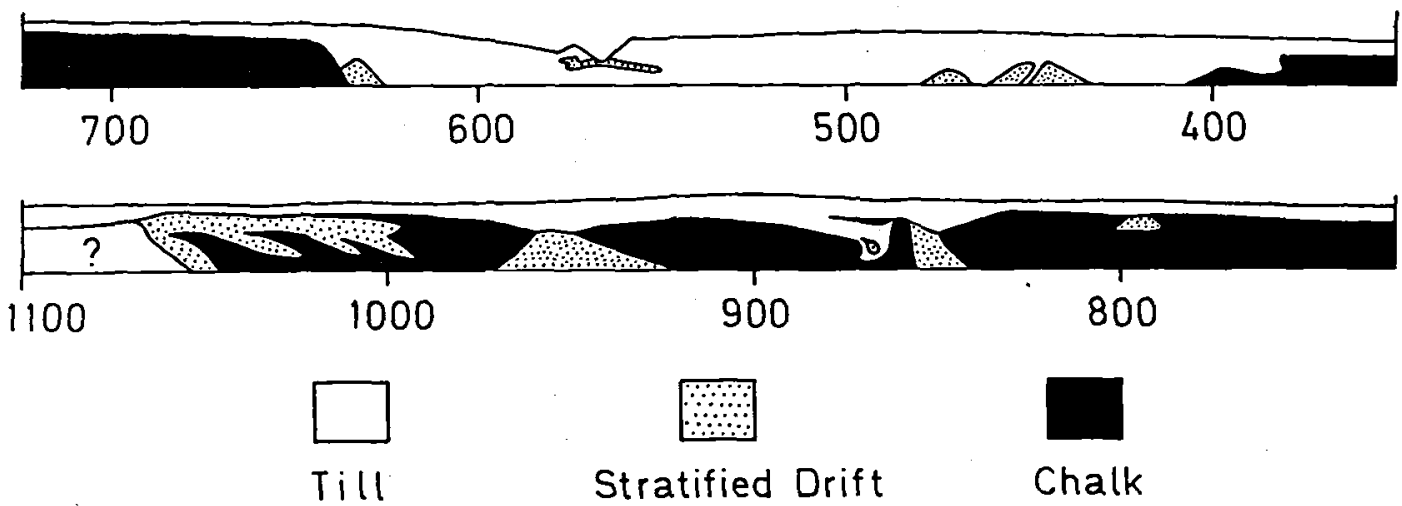

Fig. 2. Profile of central and western portions of Hvideklint showing general features. Deformed drift covers, separates, and partly underlies four large chalk floes. True scale; see Fig. 3 for details. 

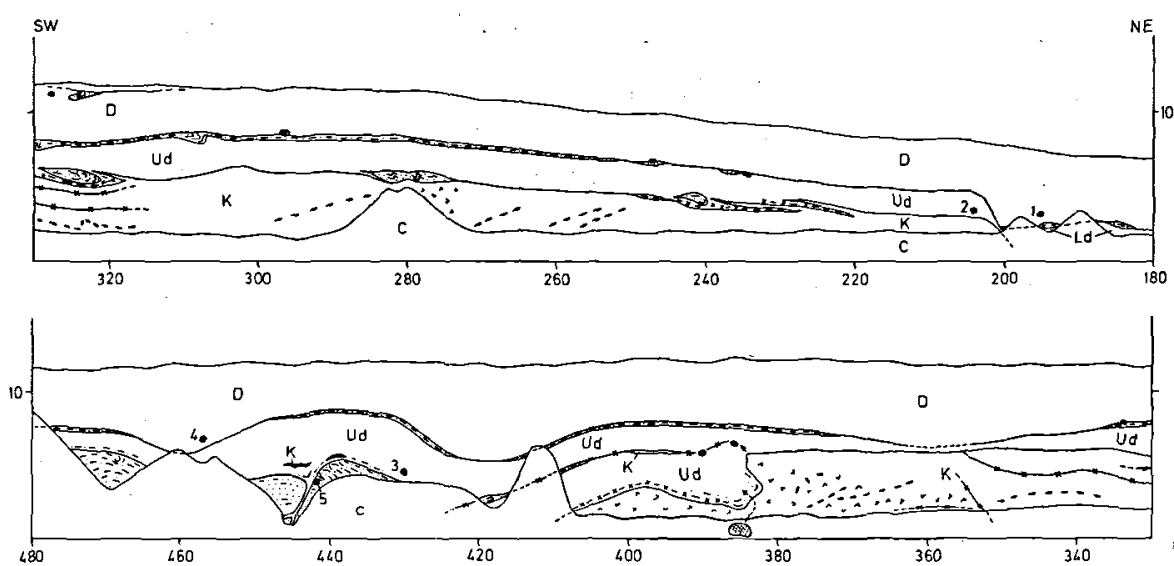
$D=$ Discordant Till
Ud = Upper Dislocated Till
Contact
Ld = Lower Dislocated Till
Uncertain or Covered Contact
$K=$ Chalk
Fault
$C=$ Cover
... Chert-Nodule Layer
7. Sample Locality
Stratified Sand, Silt, or Gravel
Chälk-Till Mélange
E:As Brecclated Cralk

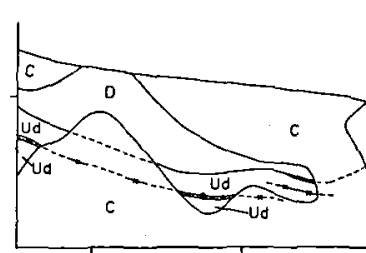

620600
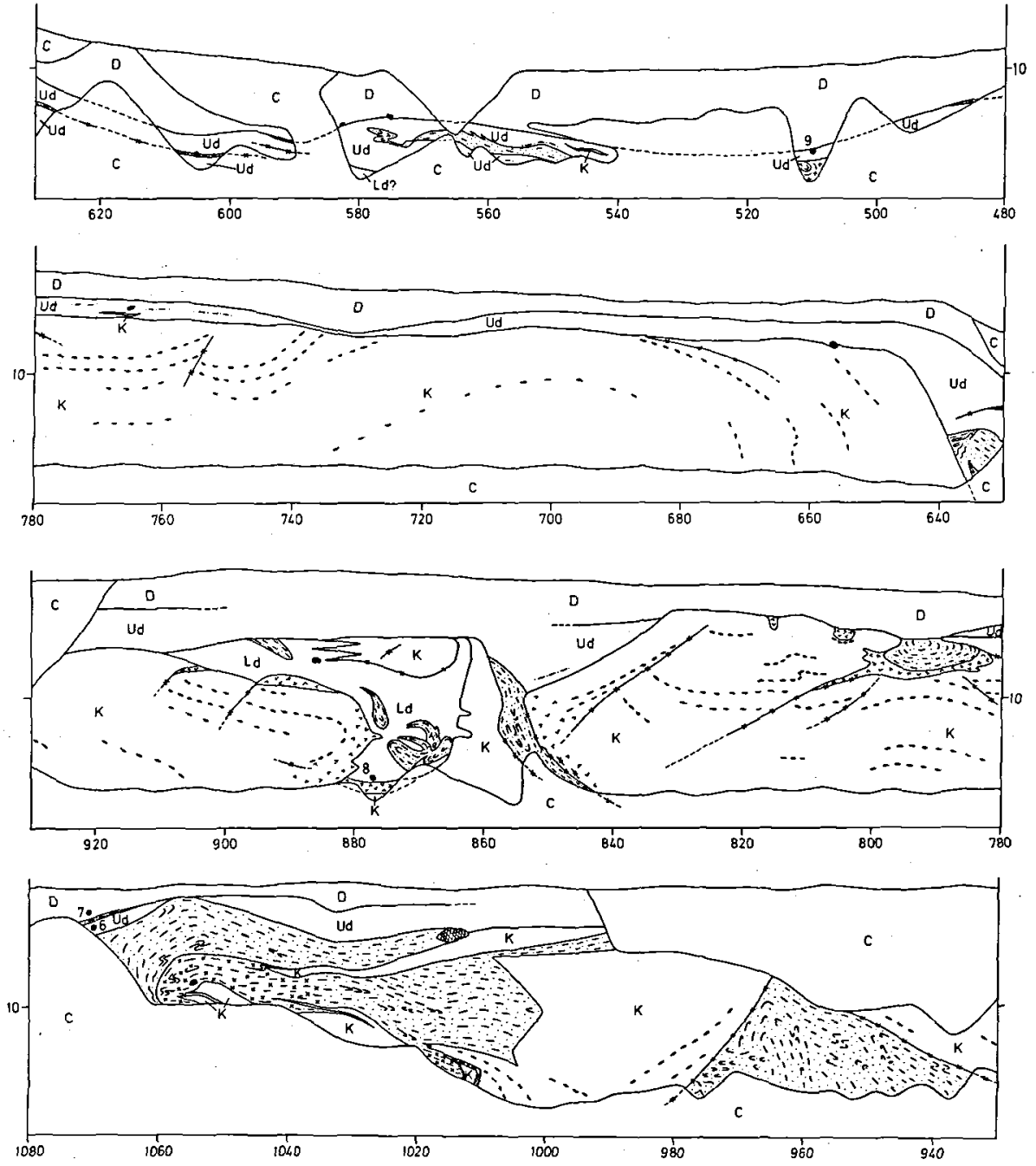

Fig. 3. Detailed profile of Hvideklint section. Base line of section is at beach level (about 1-2 $\mathrm{m}$ above sealevel), and the zero point of the base measurement is located northeast of the section, where the road (Ørebæksvej) runs onto the beach at the fishing hamlet. Note that the $2 \mathrm{x}$ vertical exaggeration slightly distorts some structures. 


\section{Method}

A detailed investigation of the Hvideklint section utilizing the kineto-stratigraphic principle was undertaken to answer some of the conflicting opinions concerning the glacial history of western Møn. The cliff section was first measured from northeast to southwest along the beach in $20 \mathrm{~m}$ segments, with the starting point of measurement placed where the road (Ørebæksvej) descends to the beach at the little fishing hamlet just northeast of Hvideklint. Each $20 \mathrm{~m}$ segment was then sketched at a horizontal scale of 1:400 and a vertical scale of 1:200 giving a $2 x$ vertical exaggeration. By using this large scale, it was possible to map individual boulders and thin strata. The segments are assembled and shown somewhat reduced in Fig. 3. The orientations of glaciodynamic structures were measured, and 10-20 kg samples of drift collected for pebble counts and study of foraminifera. All field observations were made during the spring and early summer of 1979 .

\section{Observations}

Description of the Hvideklint Section.

The stratigraphy of Hvideklint can be summarized as follows (fig. 4). A discordant till which continues across the entire cliff profile overlies an upper and lower dislocated tills. The discordant and upper dislocated tills are separated by a discontinuous sandy seam that is marked by ocassional boulders. In the upper dislocated till, large xenolithic bodies of deformed stratified drift are found at or near its base, while the lower dislocated till also includes some extremely contorted lenses of stratified drift. The drift overlies detached floes of chalk in which chalk breccia and chlak-till mélange are locally developed. In general, deformation of both drift and chalk increases toward the southwest end of the section. Thus, the cliff can be conveniently divided into four portions from northeast to southwest for detailed description.

Eastern Chalk Floe - The eastern chalk floe $(180-410 \mathrm{~m})$ is only slightly deformed compared to the other chalk floes. Chert-nodule layers show that the chalk is tilted about $15^{\circ}$ toward the southwest. A few minor thrust faults marked by $\mathrm{cm}$-thick mylonitic zones dip to the northeast,

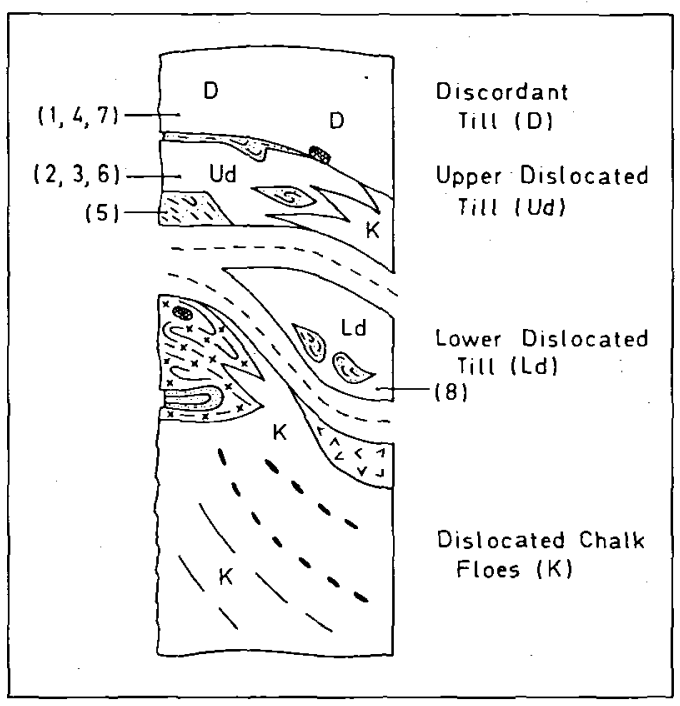

Fig. 4. Composite stratigraphic column for Hvideklint: Three till units with associated stratified drift overlie detached chalk floes. Numbers indicate stratigraphic positions of samples. Symbols same as in Fig. 3.

and along some of these thrusts the chalk is pushed upward into the overlying drift. In a few places, the upper portion of the floe consists of broken, angular chunks of chalk. Within these breccia zones, chert nodules may also be shattered. This brecciation is mostly found toward the west end of the chalk floe, where there are also a few small folds shown by the chert layers. At 385 $\mathrm{m}$, the large crystalline boulder noted by Berthelsen at al. (1977, p. 99) is now found on the beach at the base of the cliff. Formerly, this boulder lay in a hollow on top of the chalk floe, and was presumably pressed into the chalk by overriding ice.

Two tills overlie the eastern chalk floe. These tills are separated by a sandy seam generally $50-100 \mathrm{~cm}$ thick which contains scattered boulders and small, overturned folds. The sandy seam is fairly continuous, but pinches out over the east end of the chalk floe. The continous contact between the discordant and upper dislocated tills is still quite noticible, though, due to a colour and weathering contrast, and this contact drops down suddenly at the east end of the chalk.

The upper dislocated till is gray in fresh exposures, stony, chalk-rich, and broken by widely spaced $(30-40 \mathrm{~cm})$ vertical joints. It weathers to a light gray colour and forms a smooth cliff face. It is generally about two $m$ thick through most of 
the Hvideklint section, but may thin to less than one $\mathrm{m}$ and even pinch out. In places, the lower discordant till is conspicuously banded with sand laminations and thin pebble beds, and small floes of chalk from only a few $\mathrm{cm}$ up to about one $\mathrm{m}$ thick and a few m long are common. The sand laminations and thin chalk floes frequently display small isoclinal folds. Above the eastern chalk floe, three lenses of stratified drift all showing overturned isoclinal or pinched folds were observed near the base of the upper dislocated till.

The discordant till is dark brown in fresh exposures, sparsely stony, and cut by closely spaced $(10-20 \mathrm{~cm})$ vertical joints. It weathers to an orange-brown colour and forms a rough cliff face. Banding, small chalk floes, or xenolithic sand bodies are not so prominent. The discordant till is continuous across the entire Hvideklint profile, usually 3-5 m thick. At $320 \mathrm{~m}$, there appears to be a separate uppermost till about one $m$ thick overlying a folded sand lens at the top of the main discordant till. This thin till could not by traced far, and so is not shown as a sepatate unit.

At the western end of the eastern chalk floe
$(385-420 \mathrm{~m})$, the upper dislocated till appears to be repeated in the section along a thrust fault marked by a thin chalk floe, boulders, and a sandy seam. This thrust along with the chalk surface below dip westward and disappear beneath cover. The thrust fault begins just above the former position of the large boulder mentioned above.

Central Drift Sequence - Both the discordant and upper dislocated tills continue across this portion of the Hvideklint section (410-640 m). Chalk was observed below the tills at only one place in this portion $(510 \mathrm{~m})$, and this consists of chalk-till mélange rather than solid chalk. In addition, a small exposure of a third till was seen below the upper dislocated till at one spot $(580 \mathrm{~m})$. This till may be the same as the lower dislocated till discussed later. Most conspicuous in this portion are a number of large xenolithic bodies of deformed stratified drift found near the base of the upper dislocated till. Such xenoliths within Danish till are not uncommon and have been known for many years (Ussing 1913, p. 235).

At $445 \mathrm{~m}$, a »till wedge « separates two large

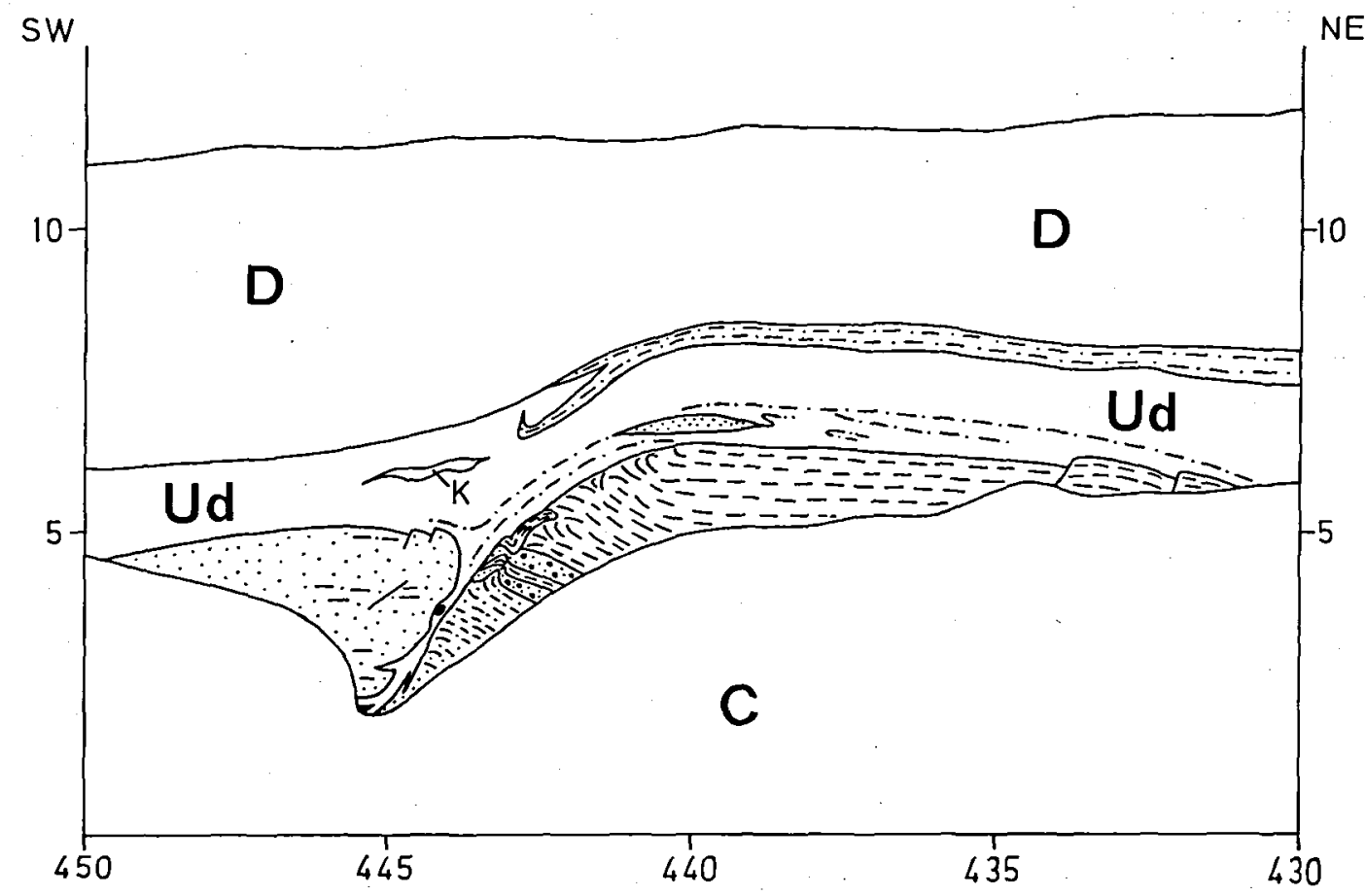

Fig. 5. Diagram of till wedge in the central drift sequence. Note downward bifurcation of till wedge and included cobble, deformation of adjacent sand body, and banding in upper dislocated till. Symbols same as in Fig. 3; true scale. 
sand xenoliths (fig. 5). The two sand bodies are quite different in character. The eastern one consists of laminated fine sand and silt beds with some ripple cross-laminations over coarser interbedded sands and gravels. The western sand body is massive coarse sand with only vague laminations. Above the eastern sand body, the overlying upper dislocated till is marked by thin sandy bands and a lens of well-sorted medium sand. At least one of the lower sandy bands could be traced over the eastern sand body and into the top of the wedge, but higher sandy bands cut across the top of the wedge. Immediately under the till wedge, the eastern sand body is folded. Close examination showed that these folds curve both upward and downward against the wedge, and thus could not be a drag phenomenon. Rather, the folds appear as if they were pushed or squeezed directly against the till wedge.

An attempt to reach the bottom of the wedge by digging was unsuccessful, but it did reveal that the wedge branches downward several times, while curving to the south. Laminations in the till wedge were most obvious where they curve smoothly around cobbles, and the laminations are generally parallel to the wedge surface. The orientation of the upper wedge surface measured near the top is $80^{\circ} / 60^{\circ} \mathrm{S}$, and the wedge surface here shows a conspicuous lineation of grooves and ridges (a few $\mathrm{cm}$ in relief) approximately parallel to the wedge surface dip direction.

A little to the southwest of the till wedge, a broken, but still articulated, clam shell was found resting in a thin gravelly sand lens about $30 \mathrm{~cm}$ beneath the top of the upper dislocated till (locality $9,510 \mathrm{~m}$ ). This specimen has been identified as either Tapes or Vensus by N. Noe-Nygaard. It is certainly of marine origin, and it could have been reworked in a frozen state along with the surrounding drift. No other Quanternary macroscopic fossils were observed in the Hvideklint section. Near the western end of the central drift sequence, the structure is more complex, and the upper dislocated till appears to be repeated in the section along a thrust fault marked by a sandy seam and boulders.

Central Chalk Floe - This is the largest single chalk floe exposed at Hvideklint (640-855 m). It rises suddenly at the east and ends to the west above a major overthrust zone. Adjacent to the

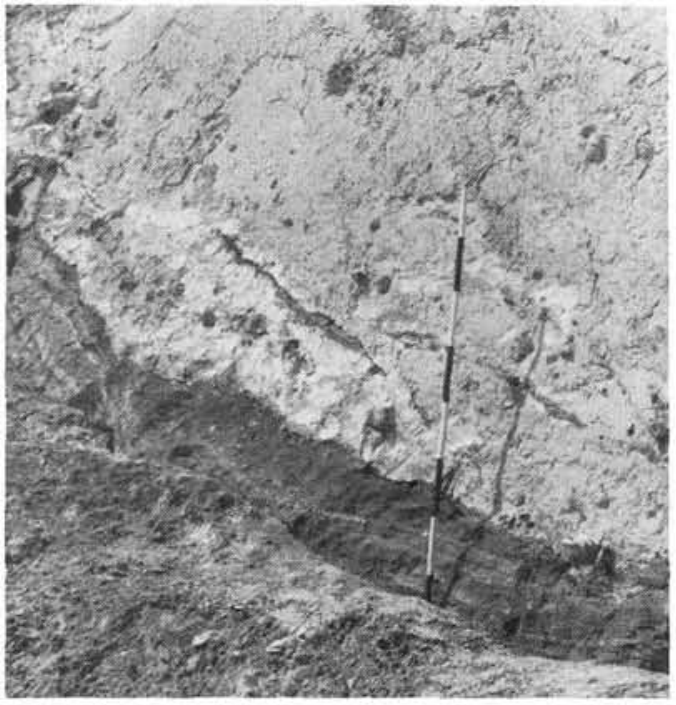

Fig. 6. Photograph of major overthrust zone $(845-850 \mathrm{~m})$ beneath west end of the central chalk floe. Thrust-parallel banding is developed in stratified drift below the chalk. Thrusting here is from the northeast. Scale pole shows $20 \mathrm{~cm}$ long stripes.

chalk overthrust ( $840-860 \mathrm{~m})$, all primary structures in the stratified drift have been destroyed by isoclinal folding, and directly under the chalk a thrust-parallel banding is developed. The orientation of this banding was measured at $162^{\circ} / 32^{\circ} \mathrm{NE}$, indicating thrusting from the northeast. In the chalk itself here, thin slivers of drift have been pushed up along small conjugate thrusts (fig. 6).

A range of glaciotectonic structures was observed within the chalk floes. To the east, chert-nodule layers outline a broad anticline, while to the west several thrust faults cut through the chalk. These thrust faults form a conjugate system which centres on an infolded syncline of stratified drift at the top of the chalk floe $(780-800 \mathrm{~m})$. The trusts dip in opposite directions away from that point and a chalk breccia zone is developed there. The net effect of these faults is an overall shortening of the central chalk floe.

The discordant and upper dislocated tills continue across the eastern portion of the central chalk floe, but toward the west the upper dislocated till thins and disappears over the infolded syncline structure. This till appears again, however, above the far western edge of the chalk floe. 
Western Chalk Floes - These two chalk floes and drift comprise the most severely disturbed portion of Hvideklint $(855-1080 \mathrm{~m})$. Near the east end of this portion, a large body of till containing extremely contorted lenses of stratified drift is almost enclosed by deformed chalk ( $860-890 \mathrm{~m})$. This lower dislocated till is clearly separated from the overlying upper dislocated till. The lower dislocated till is dark gray, stony, chalk-poor, and massive here. It overlies a chalk breccia zone that shows a transition upward from solid chalk, through chalk breccia, to chalk mylonite, and finally a sharp contact with the till.

The section presented here includes two separate chalk floes, and thus differs from the more generalized section of western Hvideklint shown by Berthelsen (1979, fig. 6). His sketch, made in 1976 , shows a single continuous chalk floe arching over stratified drift $(940-980 \mathrm{~m})$. Since 1976 , erosion has removed the chalk here, and hence a continuous chalk outcrop could no longer be observed. In any case, major overthrusts are shown at the bases of the chalk floes. All primary structures in the underlying stratified drift have been completely erased by penetrative folding.

The western end of Hvideklint displays an extreme stretching and thinning of the chalk floes toward the southwest $(1000-1060 \mathrm{~m})$. The chalk

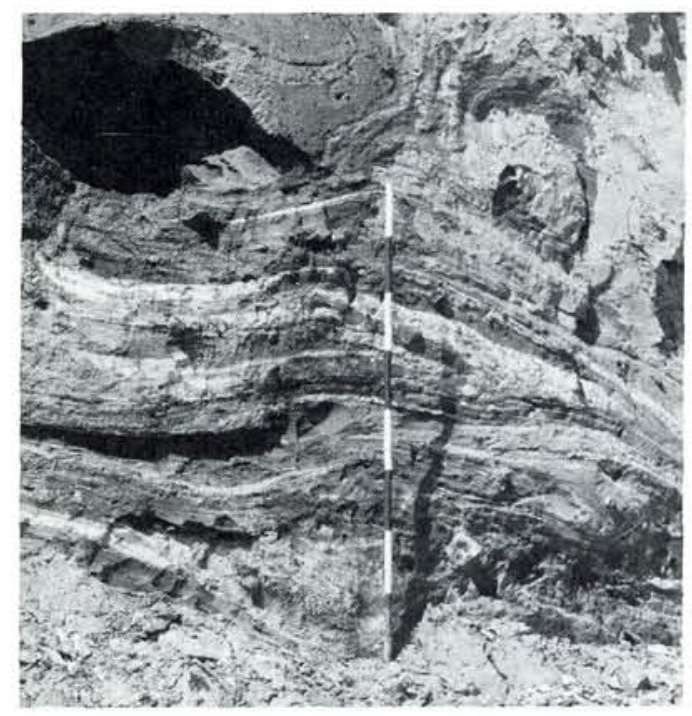

Fig. 7. Example of chalk-till mélange from western portion of Hvideklint. Note stretched isoclinal folds, inclusion of exotic boulders, and seeming chaotic appearance of interbedded chalk, banded till, and sand. Scale pole shows $20 \mathrm{~cm}$ long stripes. here splits into several thin floes interbedded and folded together with chalk-banded till and stratified drift. Penetrative deformation has resulted in an intimate mixture of chalk and drift which shows stretched isoclinal folding and shear lamination. This sort of material has been mapped as »chalk-till mélange« (fig. 7).

Overlying the chalk-till mélange (1020-1060 $m$ ) is a unit of isoclinally folded sand which wraps around the west end of the mélange. A large recumbent fold with a core of chalk-till mélange is thus indicated. Berthelsen (1979, fig. 6) has observed a separate sand unit outcropping beneath the chalk-till mélange, and so the major thrust below the westernmost chalk floe may extend on to the west. Both the discordant and upper dislocated tills continue over this portion of Hvideklint, although the upper dislocated till pinches out briefly above the crest of the large recumbent fold $(1055 \mathrm{~m})$.

Structural Measurements - The orientations of glaciodynamic structures measured along the Hvideklint section fall in the north-west and southeast quadrants (fig. 8). Fold axes were measured in deformed stratified drift found in

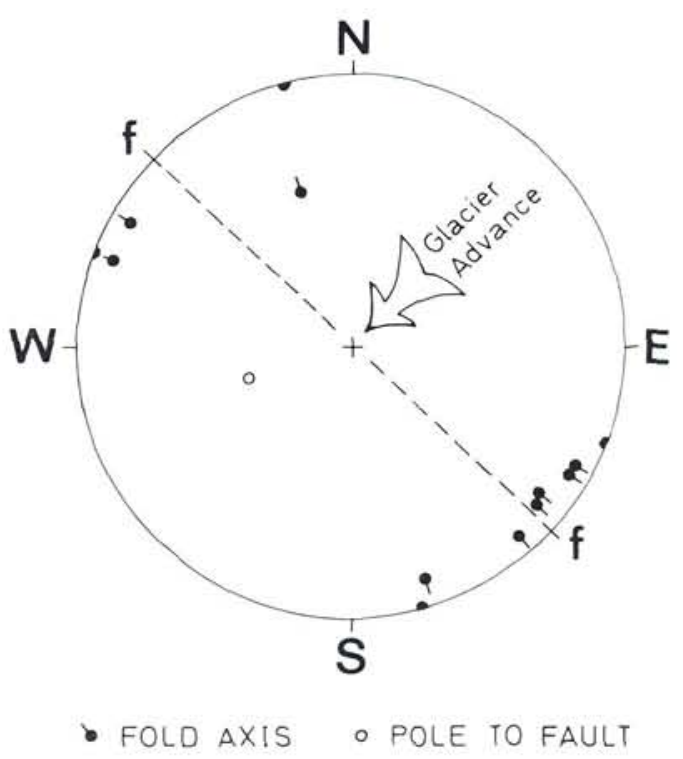

Fig. 8. Equal-area plot of structural data from Hvideklint. Fold axes were measured in deformed stratified drift, and the fault shown is the major overthrust at $840-860 \mathrm{~m}$. Line $\mathrm{f}-\mathrm{f}$ shows the average trend of fold axes $\left(133^{\circ}-313^{\circ}\right)$. Inferred direction of ice movement which caused these deformations is from the northeast. 
between the western chalk floes and in xenolithic bodies within the upper dislocated till. The fold axes are with only one exception near horizontal and all trend either southeast or northwest, the average trend being $133^{\circ}-313^{\circ}$. It was impossible to reach and actually measure the axes of folds in the sandy seam that separates the discordant and upper dislocated tills, but these fold axes appear to trend about the same as measured folds (SE-NW). The major overthrust beneath the western end of the central chalk floe also strikes SE-NW. These structural data as well as the southwestward stretching of the western chalk floe indicate an ice movement direction from northeast to southwest at Hvideklint. There and nearby at the Vagtbo Bakke cliff (fig. 1), a couple of isolated boulders showing NE-SW trending striations were observed within the discordant till unit.

Drift Composition - Eight samples of drift from Hvideklint (localities 1-8, figs. 2 and 3) were collected for pebble counts and foraminifera analysis. Two size fractions were counted to establish pebble composition: $6 \mathrm{~mm}-6 \mathrm{~cm}$ (Ussing \& Madsen 1897) and 3-5 mm (Ehlers 1978). In the larger size fraction (table 1), samples from the discordant $(1,4, \& 7)$ and upper dislocated $(2,3$, \& 6) tills appear generally the same, especially when the composite samples $(1+4+7$ and
Table 1. Pebble-count data $(6 \mathrm{~mm}-6 \mathrm{~cm}$ size $)$ from Hvideklint. Samples 1, 4, and 7 are from the discordant till; 2,3 , and 6 from the upper dislocated till; 5 from a gravelly sand body in the upper discordant till; and 8 from the lower dislocated till. Column labelled »size « shows number of pebbles counted for each sample.

\begin{tabular}{|c|c|c|c|c|c|c|c|c|c|c|}
\hline samp & size & flint & $\begin{array}{c}* \\
\text { white } \\
\text { chalk }\end{array}$ & $\begin{array}{l}\text { x } \\
\text { hard } \\
\text { chalk }\end{array}$ & $\begin{array}{c}x \\
g l a u c \\
\text { ss+ch }\end{array}$ & $\begin{array}{l}\text { L ime- } \\
\text { stone }\end{array}$ & $\begin{array}{l}x \\
5 \text { and- } \\
\text { stone }\end{array}$ & $\begin{array}{c}* \\
\text { shale }\end{array}$ & $\begin{array}{c}x \\
\text { cryst }\end{array}$ & $\begin{array}{c}x \\
\text { other }\end{array}$ \\
\hline 1 & 14 & 0.0 & 35.7 & 0.0 & 7.1 & 7.1 & 14.3 & 0.0 & 35.7 & 0.0 \\
\hline 2 & 159 & 8.8 & 30.2 & 2.5 & 1.3 & 18.2 & 4.4 & 9.4 & 25.2 & 0.0 \\
\hline 3 & 138 & 5.8 & 38.4 & 0.7 & 3.6 & 19.6 & 6.5 & 5.1 & 20.3 & 0.0 \\
\hline 4 & 70 & 8.6 & 27.9 & 4.3 & 2.9 & 17.1 & 4.3 & 7.1 & 27.1 & 1.4 \\
\hline 5 & 182 & 15.9 & 3.3 & 12.1 & 4.9 & 7.7 & 5.5 & 12.6 & 36.8 & 1.1 \\
\hline 6 & 233 & 7.3 & 53.6 & 0.4 & 2.6 & 7.7 & 4.3 & 5.2 & 18.9 & 0.0 \\
\hline 7 & 47 & 2.1 & 29.8 & 8.5 & 0.0 & 19.8 & 6.4 & 6.4 & 27.7 & 0.0 \\
\hline 8 & 151 & 2.0 & 0.0 & 4.0 & 1.3 & 31.1 & 15.2 & 15.2 & 31.1 & 0.0 \\
\hline $1+4+7$ & 131 & 5.3 & 29.0 & 5.3 & 2,3 & 16.8 & 6.1 & 6.1 & 28.2 & 0.8 \\
\hline $2+3+6$ & 530 & 7.4 & 42.6 & 1.1 & 2.6 & 14.0 & 4.9 & 6.4 & 21.1 & 0.0 \\
\hline
\end{tabular}

$2+3+6$ ) are compared. In sharp contrast, sample 8 from the lower dislocated till has noticibly less Cretaceous chalk and more Paleozoic limestone. Sample 5 from the gravelly sand xenolith below the till wedge has much higher percentages of the hard rock types such as flint and crystallines.

Two triangular diagrams, whose components indicate drift provenance, have been prepared (fig. 9). The left-hand diagram shows local rock types (flint + chalk + glauconitic chalk \& sandstone) versus crystalline rock types versus Baltic rock types (Paleozoic limestone + sandstone + shale), while the right-hand diagram shows only exotic rock types normalized to $100 \%$. On this basis, the discordant and upper

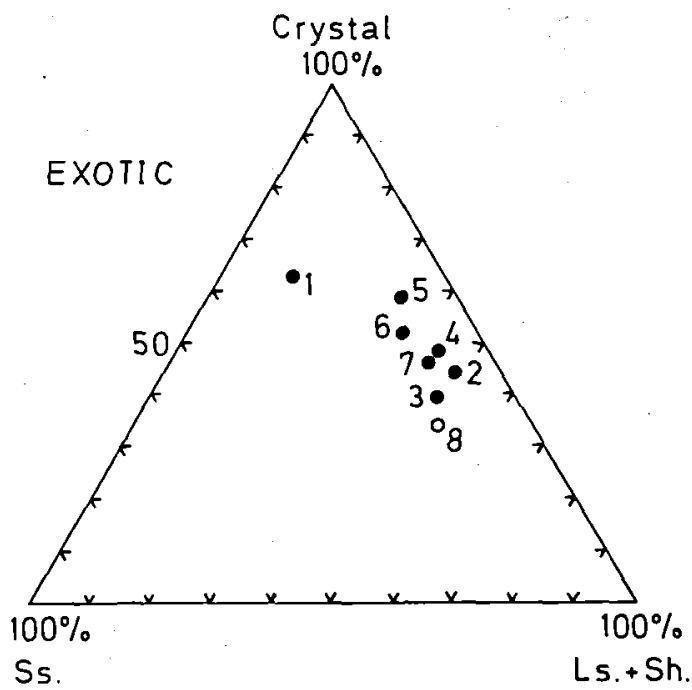

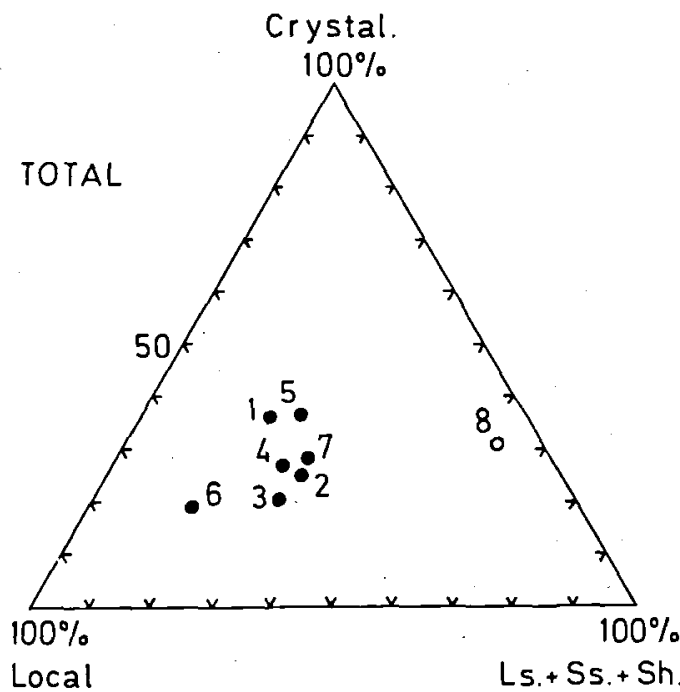

Fig. 9. Triangular diagrams showing pebble-count data $(6 \mathrm{~mm}-6 \mathrm{~cm}$ size) from Hvideklint. Discordant and upper dislocated till samples (solid dots) appear generally similar, whereas sample 8 (open dot) from the lower dislocated till is noticibly different. 
dislocated tills (and also sample 5) seem to be quite similar, characterized by a large amount of local material and about equal contents of crystalline and Paleozoic types. Only sample 8 from the lower dislocated till is conspicuously different, with an extremely low content of local rock types and a high proportion of Paleozoic limestone. (Sample 1 may be somewhat unreliable by itself due to its small size).

Data from the smaller size fraction, analysed by S. Sjørring, show similar features (table 2). Samples from the discordant and upper dislocated tills are much alike, while sample 5 has noticeably more flint and crystalline granules and less chalk. Here again, sample 8 is most different, marked by extremely small amounts of chalk and flint and larger quantities of Paleozoic limestone, sandstone, and shale. These differences show clearly when the data are displayed graphically (fig. 10) following the format of Ehlers (1978).

The eight drift samples from Hvideklint were also examined for foraminifera content by $\mathrm{J}$. Frederiksen. Of the eight, only three samples $(2,3$, and 4) contained sufficient Quaternary foraminifera to draw any conclusions. These three samples from the upper dislocated and dis-
Table 2. Granule-count data (3-5 $\mathrm{mm}$ size) from Hvideklint Data show the same general features as in the larger size fraction (see table 1).

\begin{tabular}{|c|r|r|r|r|r|r|r|}
\hline Samp & size & $\begin{array}{c}\% \\
f l i n t\end{array}$ & $\begin{array}{c}\% \\
\text { chalk }\end{array}$ & $\begin{array}{c}\% \\
\text { lime- } \\
\text { stone }\end{array}$ & $\begin{array}{c}\% \\
\text { Ss+5h }\end{array}$ & $\begin{array}{c}\% \\
\text { cryst }\end{array}$ & $\begin{array}{c}\% \\
\text { acz }\end{array}$ \\
\hline 1 & 110 & 3.6 & 30.9 & 26.4 & 12.7 & 22.7 & 3.6 \\
2 & 649 & 6.3 & 30.2 & 23.6 & 8.3 & 30.8 & 0.8 \\
3 & 918 & 5.3 & 39.2 & 18.1 & 12.5 & 23.4 & 1.4 \\
4 & 521 & 5.6 & 32.5 & 20.5 & 8.6 & 30.5 & 2.3 \\
5 & 601 & 13.3 & 8.8 & 21.5 & 18.3 & 37.6 & 0.5 \\
6 & 948 & 5.2 & 50.0 & 16.4 & 9.6 & 18.1 & 0.7 \\
7 & 220 & 3.2 & 34.6 & 25.5 & 10.5 & 25.5 & 0.9 \\
8 & 583 & 0.7 & 2.1 & 42.0 & 19.6 & 34.5 & 1.2 \\
\hline $1+4+7$ & 859 & 4.7 & 32.8 & 22.6 & 9.6 & 28.2 & 2.1 \\
$2+3+6$ & 2515 & 5.5 & 40.9 & 18.8 & 10.3 & 23.3 & 1.0 \\
\hline
\end{tabular}

cordant tills show a variety of foraminifera with Nonion germanicum, $N$. orbiculare, Elphidium albiumbilicatum, and E. excavatum the dominant species. These are warm-sea species and presumably reworked from the Eemian marine strata which occur around Møn (Berthelsen et al. 1977). On this basis, the upper dislocated and discordant tills are of Weichselian age.

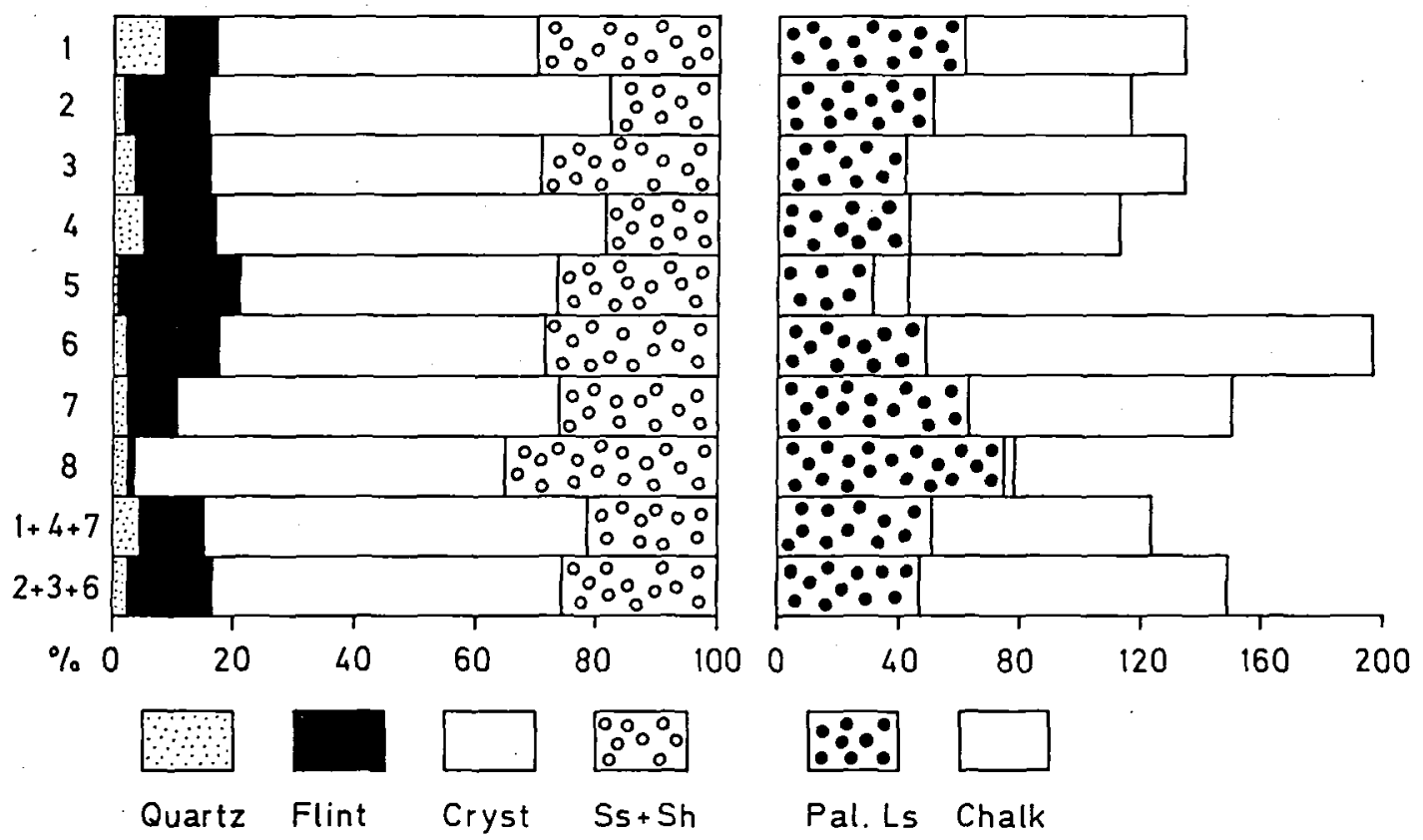

Fig. 10. Diagram of granule-count data (3-5 mm size) from Hvideklint following the format of Ehlers (1978). The left-hand portion shows the non-carbonate fraction normalized to $100 \%$. The right-hand side shows carbonates as a percentage of the non-carbonate fraction. Sample 8 from the dislocated till stands out clearly. 
Interpretation and Regional Significance

Kineto-Stratigraphy - All the structural evidence suggest that the thrusting and deformation at Hvideklint were caused by glacier advances coming from the northeast. Thus, it seems likely that the chalk floes were transported from the present-day Fakse Bugt area, as proposed by Berthelsen (1979), and probably not thrust up from Hjelm Bugt, as Surlyk (1971) suggested.

The discordant and upper dislocated tills are on the basis of structural data ascribed to two separate glacier advances from the northeast. On westernmost Møn at Madsesklint (fig. 1), Berthelsen et al. (1977) interpreted a complex Northeast drift unit, "... as due to repeated small retreats and advances during a general advance of an ice stream from the northeast 94, translated). Farther west, on the island of Als, Sjørring (1977) has likewise shown that the Northeast Advance included at least one readvance. Thus, the Northeast Advance appears to have actually comprised two or more advances and readvances in southern Denmark. The lower dislocated till is, then, assigned to the Old Baltic Advance. There is apparently no strong evidence for a Young Baltic Advance at Hvideklint, although there is good evidence for a Young Baltic Advance elsewhere on Møn, for example at Madsesklint (Berthelsen et al. 1977) and at Møns Klint (Berthelsen 1979).

In general, it is believed that glaciotectonic thrusting of large, detached floes took place in the permafrost layer immediately in front of advancing glaciers (Jessen 1931, Gry 1940, Berthelsen 1979). Thus, the chalk floes at Hvideklint as well as the lower dislocated till body were probably pushed into their present positions in front of the initial Northeast advance. As this first Northeast advance overrode the area, the chalk-till mélange was created by penetrative shearing and folding, and then the upper dislocated till was laid down. It too was subjected to penetrative deformation. The structural complexity of the chalk-till mélange and upper dislocated till may indicate that the ice margin oscillated during the initial Northeast advance. Following an ice-margin retreat and perhaps a change in ice-sheet regime, a later Northeast readvance deposited the discordant till, and ap- parantly caused little additional disturbance of the Hvideklint section.

Gry (1940) has noted that the intensity of deformation within disturbed sequences is often greatest on the stoss side and decreases in a down-ice direction. However, the opposite situation is found at Hvideklint, where deformation is more complex toward the southwest. One possible explanation is that many of the smaller glaciotectonic structures may have developed subglacially due to simple shear deformation, which took place after ice overrode the area and large-scale thrusting had ceased (Berthelsen 1979). The chalk-till mélange as well as the upper dislocated till were probably created subglacially in this manner.

The chalk-till mélange (fig. 7) is so called because it closely resembles true tectonic mélanges, but at Hvideklint its origin is surely glacial. In a more general sense, it could be called a glaciodynamic mélange, here defined as: material consisting of both pre-existing substrata and drift chaotically mixed together, penetratively folded and sheared, and deposited by an overriding glacier. A glaciodynamic mélange, thus, represents material intermediate in character between glacially deformed substrata and true, homogeneous till, and so corresponds to the zone of penetrative glacial deformation of Banham (1977). A word of caution is necessary here, for some of the fold structures in the chalk-till mélange superficially resemble soft sediment deformations described by Evenson, Dreimanis \& Newsome (1977) from subaqueous glacial deposits. However, the subaqueous structures affect only penecontemporaneous sediments, whereas a glaciodynamic mélange includes pre-existing material, either earlier drift or bedrock.

With regard to the till wedge found in the central drift sequence, Humlum (1978) has observed a somewhat similar large till wedge in stratified drift on southern Sjælland. He interpreted that wedge as an sintrusion " which took place beneath a temperate glacier when both the till and underlying stratified drift were unfrozen. This contrasts with the view that most glaciotectonic disturbances occurred in a largely frozen state (Jessen 1931, Gry 1940, Berthelsen 1979). At Hvideklint, I believe that the xenolithic stratified bodies in the upper dislocated till were transported and emplaced as frozen bloocks 
within a partly frozen till material that may have been near the pressure-melting point. Thus, the till wedge could have formed as a semifrozen mush sequeezed in between two frozen sand bodies. The sandy bands in the till could represent small thrust surfaces along which pressure-melting took place, and folding of the xenoliths may have occurred due to local melting during or after emplacement.

Drift Composition - The pebble count data support the kineto-stratigraphic interpretation. The Baltic character of the lower dislocated till (sample 8 ) is clearly shown by its high content of Paleozoic rock types, while the discordant and upper dislocated tills are marked by high proportions of chalk and flint and not so many Paleozoic pebbles. The similarity of the latter two tills could be due to admixture of pebbles from the upper dislocated till when the discordant till was diposited. Of course, the content of local rock types in till cannot indicate whether the depositing glacier had a Baltic or Northeast origin. Nonetheless these data fit with Ehlers' (1978) findings in northern Germany and the area west of Møn in southern Denmark. He concluded that the Northeast drift is distinguished from both the Old and Young Baltic drifts due to its higher flint and chalk content. Apparantly, considerable local erosion of flint-bearing chalk bedrock occurred in the western Baltic region during the Northeast Advance, whereas the Baltic advances caused less erosion in this area.

The pebble-count data also suggest a correlation between tills at Hvideklint and Mons Klint (fig. 1). At Møns Klint, two tills, a thick upper and a thin lower, are separated by stone-poor clay and a sand layer (Hansen \& Nielsen 1960). Because the upper part of the lower till contains abundant reworked Eemian foraminifera, Konradi (1973) concluded that this till and all the overlying drift must be of Weichselian age. The drift is dislocated along with underlying chalk floes; the Young Baltic Advance supposedly caused the latest dislocations (Berthelsen 1979). A number of pebble counts $(6 \mathrm{~mm}-6 \mathrm{~cm}$ size) were carried out by Hintze (1937) on these two tills, and his data are plotted here on triangular diagrams (fig. 11). The lower till at Møns Klint, with only a small amount of chalk and flint plus a high proportion of Paleozoic limestone, corresponds exactly to the lower dislocated till at Hvideklint. (The stone-poor clay at Møns Klint may also be similar). Likewise, the upper till at
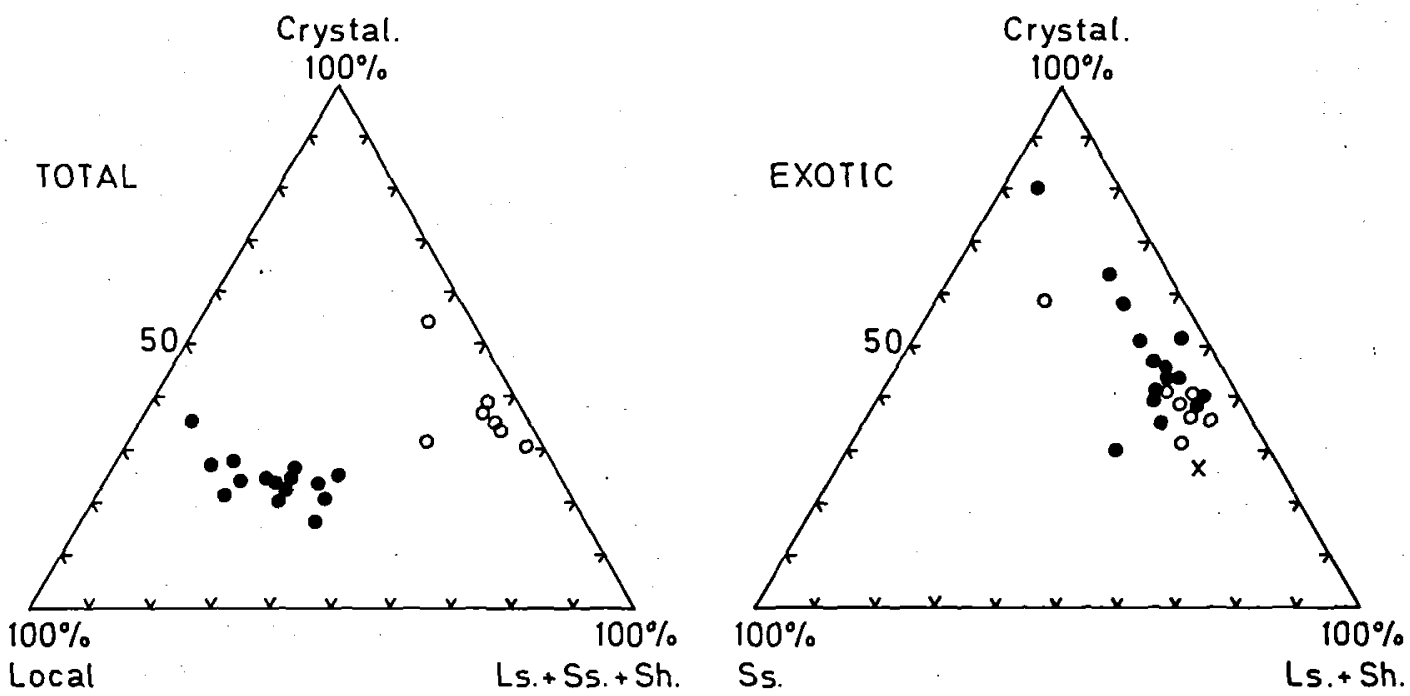

Fig. 11. Triangular diagrams showing Hintze's (1937, p. 84-87) pebble-count data (6 mm-6 cm size) from Møns Klint. Closed dots show data from the upper till (Hintze's samples 28, 29,30,31,33, 34, 35, 37, 38, 39, 40,41, 42, 43, and 44), and open dots show data from the lower till (samples $4,5,7,8,9,10$, and 12). The upper till samples are compositionally like the discordant and upper dislocated tills at Hvideklint, while the lower till data match the lower dislocated till at Hvideklint. The $X$ on exotic diagram shows a sample ( $26 \mathrm{~kg}$ with 786 clasts in the 2-6 mm fraction) from the stone-poor clay at Møns Klint (Petersen, in Berthelsen et al. 1976, p. 24). 
Møns Klint, with abundant local rock types (mostly flint), corresponds well to the discordant and upper dislocated tills at Hvideklint. On this basis, it appears that the lower and upper tills at Møns Klint can be respectively assigned to the Old Baltic and Northeast Advances - an interpretation that was indicated on the stratigraphic diagrams in Berthelsen et al. (1976, p. 19).

The Old Baltic and Northeast till sample data from Møn (figs. 9 and 11) are clearly separated when shown on the »total " triangular diagram. But on the "exotic " diagram (as used in Berthelsen et al. 1977), there is some overlap and no clear separation of data points. On average, Old Baltic samples polt closer to the limestone + shale end of this diagram, while Northeast samples plot closer to the crystalline end. But, a single pebble count cannot be definitely identified as Baltic or Northeast by using this diagram. On Møn, the »total « triangular plot, which shows local rock types as one component, seems much better for distinguishing Baltic and Northeast till samples.

The lower (Old Baltic) and upper (Northeast) tills at Møns Klint are separated by several conformable sand and clay layers, while at Hvideklint the Old Baltic and Northeast tills are separated only by a structural unconformity. There could be two reasons for the absence of similar stratified deposits at Hvideklint. First, such strata overlying the Old Baltic till may never have been present there, or more likely, any such deposits could have been reworked by the initial Northeast advance. Some of the stratified xenoliths in the upper dislocated till at Hvideklint may represent similar reworked interstadial deposits as well as other reworked drift.

\section{Conclusions}

1. - Three till units with included and intervening stratified drift are present at Hvideklint above and between detached chalk floes. A lower dislocated till is assigned to the Old Baltic Advance and corresponds to the lower till at Møns Klint. The lower dislocated till is overlain by an upper dislocated till, which in turn is covered by a discordant till. The latter two tills represent an advance and readvance by the Northeast Ice, and they correspond to the upper till at Mons Klint.
2. - The chalk floes at Hvideklint were emplaced in front of the initial Northeast advance, and were probably transported from the Fakse Bugt area. Following emplacement, subglacial deformation by overriding ice created chalk-till mélange, an example of glaciodynamic mélange. These deformations probably took place in largely frozen materials with only small quantities of water due to pressure-melting present.

3. - The Northeast drift around the western margin of the Baltic basin is marked by a large proportion of local rock types (chalk and flint), whereas Old Baltic drift has abundant Paleozoic limestone and only small percentages of local rocks. This fact, combined with kineto-stratigraphic data, could serve as a basis for correlation in the southern Denmark region.

Acknowledgements. The author was supported in this study by a Fulbright-Hays Grant from the Institute of International Education and by a grant from the Research Institute of Chadron State College. Field equipment and vehicle plus office and laboratory facilities were provided by the Institute of General Geology, University of Copenhagen. I thank all of my colleagues at the Institute, especially those whose help is noted in this report, and $A$. Berthelsen, who suggested and followed the progress of the study and reviewed this report. My wife, Susie, ably assisted with fieldwork. S. Sjørring improved the Danish summary, and $O$. Berthelsen photographed the figures.

\section{Dansk sammendrag}

Hvideklint er et ca. $1 \mathrm{~km}$ langt erosionssnit i en op til $20 \mathrm{~m}$ høj kuppelbakke, der ligger umiddelbart øst for landsbyen Hjelm på Sydmøns kyst. Klintprofilet består af forstyrrede istidsaflejringer med flager af skrivekridt. De kvartære aflejringer er blevet undersagt og opdelt $i$ enheder ved anvendelsen af det kineto-stratigrafiske princip (Berthelsen 1978).

Glacialtektoniske strukturer som f.eks. overskydninger og isoklinale folder viser, at dislokationerne i Hvideklint er frembragt af istryk fra nordøst (fig. 8) og det er tænkeligt, at kridtflagerne i Hvideklint er bragt dertil fra Fakse Bugt området nord for Møn. Kridtflagerne er skubbet op foran den fremrykkende is, der efterhånden gled hen over flagerne og frembragte nkalkmorænemélange «, et eksempel på glaciodynamic mélange (fig. 7). Dannelsen af disse isbetingede deformationer har sandsynligvis fundet sted mens morænematerialet har været permafrossent, dog har små mængder smeltevand kunnet dannes ved tryksmeltning $\mathrm{i}$ overskydningszonerne (Berthelsen 1979).

Der er tre adskilte moræneformationer med tilhørende smeltevandsaflejringer i Hvideklint (fig. $3 \circ \mathrm{og} 4$ ), nemlig en diskordant moræne og en øvre disloceret morane, der begge formodes at være aflejret af Weichsel hovedfremstødet - den såkaldte NØ-is, som nåede frem til Hovedopholdslinien i Jylland. Den nederste enhed, den nedre dislocerede moræne, tolkes som hørende til den gammelbaltiske Weichsel is. 
Stentællinger fra de tre moræner (fig. 9 og 10, tabel 1 og 2) viser, at den diskordante og den øvre dislocerede moræne har omtrent samme stenindhold (store mængder kalk og flint og mindre indhold af krystallinske og palæozoiske bjergarter), mens den nedre dislocerede moræne indeholder store mængder palæozoiske bjergarter, men til gengald kun lidt kalk og flint. Stenselskabet passer godt med Ehlers' (1978) opfattelse, at NØ-morænen i Syddanmark og Nordtyskland indeholder store mængder lokalt materiale, nemlig kalk og flint.

Pă grundlag af stentællingerne synes den diskordante og den øvre dislocerede moræner i Hvideklint at svare til den ovre dislocerede moræne i Møns Klint, og den nedre dislocerede moræne i Hvideklint synes at være den samme, som den nedre dislocerede moræne i Mans Klint (fig. 9 og 11).

De yngste glaciale forstyrrelser i Mens Klint er formodentlig frembragt af den ungbaltiske is. I Hvideklintprofilet er der ikke observeret hverken deformationer eller aflejringer fra dette isfremstød.

\section{References}

Banham, P. H. 1977: Glacitectonics in till stratigraphy. Boreas 6: $101-105$.

Berthelsen, A. 1973: Weichselian ice advances and drift successions in Denmark. Bull. geol. Inst. Univ. Uppsala N.S. 5: 21 29.

Berthelsen, A. 1978: The methodology of kineto-stratigraphy as applied to glacial geology. Bull. geol. Soc. Denmark 27 , Special issue, 25-38.

Berthelsen, A. 1979: Recumbent folds and boudinage structures formed by subglacial shear: An example of gravity tectonics. In: W. J. M. van der Linden (ed.): Van Bemmelen and his search for harmony. Geol. en Mijnbouw 58(2).

Berthelsen, A., Konradi, P., Petersen, K. S., Rasmussen, L. Aa. and Sjørring, S. 1976: Nordqua Ekskursion, 1976 til Sjalland, Falster, Møn. København, 1976, 31 pp.

Berthelsen, A., Konradi, P. and Petersen, K. S. 1977: Kvartære lagfølger og strukturer i Vestmøns klinter. Dansk geol. Foren., Arsskr. 1976: 93-99.
Ehlers, J. 1978: Fine gravel analyses after the Dutch method as tested out on Ristinge Klint, Denmark. Bull. geol. Soc. Denmark 27: 157-165.

Evenson, E. B., Dreimanis, A and Newsome, J. W. 1977: Subaquatic flow tills: $A$ new interpretation for the genesis of some laminated till deposits. Boreas 6: 115-133.

Gripp, K. 1948: Jasmund und Möen, eine glazialmorphologische Untersuchung. Zeitsch. Erdkunde 1: 175-182.

Gry, H. 1940: De istektoniske forhold i moleromraadet. Meddr. Dansk geol. Foren. 9: 586-627.

Hansen, S and Nielsen, A. V. 1960: Glacial geology of southern Denmark. Guide to Excursions Nos A44 and C39, Intern. Geol. Congr., XXI Session, Norden.

Hintze, V. 1937: Moens Klints geologi. C. A. Reitzel, Copenhagen, $410 \mathrm{pp}$.

Humlum, O. 1978: A large till wedge in Denmark: Implications for the subglacial thermal regime. Bull. geol. Soc. Denmark 27: 63-71.

Haarsted, V. 1956: De kvartærgeologiske og geomorfologiske forhold på Møn. Medd. Dansk geol. Foren. 8: 124-126.

Jacobsen, E. M. 1976: En morænestratigrafisk undersøgelse af klinterne på Omø. Dansk geol. Foren., Arsskr. 1975; 15-17.

Jessen, A. 1931: Lønstrup Klint. Danm. geol. Unders. rk. 2, 49: $142 \mathrm{pp}$.

Konradi, P. B. 1973: Foraminifera in some Danish glacial deposits. Bull. geol. Inst. Univ. Uppsala N. S. 5: 173-175.

Petersen, K. S. and Konradi, P. B. 1974: Lithologisk og paleontologisk beskrivelse af profiler i kvartæret på Sjælland. Dansk geol. Foren., Arsskr. 1973: 47-56.

Sjerring, S. 1977: The glacial stratigraphy of the island of Als, southern Denmark. Z. Geomorph. N. F., Suppl.-Bd. 27: 1-11.

Smed, P. 1962: Studier over den fynske ogruppes glaciale landskabsformer: Medd. Dansk geol. Foren. 15: 1-74.

Surlyk, F. 1971: Skrivekridiklinterne på Møn. Varv, Ekskursionsfører 2: 5-24.

Ussing, N. V. 1913: Danmarks geologi. Danm. geol. Unders. rk 3, 2: 372 pp.

Ussing, N. V. and Madsen, V. 1897: Kortbladet Hindsholm. Danm. geol. Unders. $r k$ 1, 2: $87 \mathrm{pp}$. 